\title{
A tribute to the memory of Professor Masuzo Shikata
}

Professor Dr. Masuzo Shikata, the Honorary President of the Society, died a peaceful death by an apoplectic stroke at his home of Yoshida-honmachi 5, Sakyo-ku, Kyoto at 9:20 in the evening on 8th May 1964. He is a great loss to all the polarographers abroad as well as in this country.

The late Professor Masuzo Shikata was born in Tokyo on 10th August 1895. He spent his boyhood days in Mito near Tokyo. He was educated in Tokyo and was graduated from the Department of Agricultural Chemistry of the Imperial Univessity of Tokyo in 1920. Already at that time he had much interest in organic electrochemistry, and after graduation from the Universty he studied on electrochemical oxidation of benzene to benzoquinone under Professor Umetaro Suzuki at the Research Institute of Physics and Chemistry (Rikagaku Kenkyusho) in Tokyo. In 1921 he was appointed to a student abroad by the Ministry of Education and visited Berlin, where he studied on surface chemistry under Professor I. Traube in the Technische Hochschule in Berlin. About that time Professor Jaloslaw Heyrovsky started original and fruitful researches of electrochemisty with the dropping mercury electrode. Young Shikata was deeply interested in this work and finally in 1923 he joined in Heyrovsky's group in Prague. Under Professor Heyrovsky he studied on the electroreduction of nitrobenzene with the dropping mercury electrode. This was the first polarographic study of organic substances with the dropping mercury electrode (Trans. Faraday Soc., 21, 24 (1925), J. Agric. Chem. Soc., Japan, 1, 533 (1925). During the course of this study he discovered for the first time the maximum phenonomena of polarographic current, to which he gave an explanation based on adsorption and desorption of netrobenzene at the electrode surface. Until the year 1924 the current-voltage curves were obtained manually point by point on section paper. It took a couple of hours of laborious work to obtain a full curve from 0 to -2 applied voltage. In 1924 Heyrovsky and Shikata invented an instrument-the polarograph-, which records the current-voltage curves-the polarogram-automatically on photographic paper in less than ten minutes with all the advantage of automatic and continueous recording (Rec. trav. chim. phys. Pay-Bas, 44, 496 (1925). According to the apparatus "polarograph", the electrochemical researches with the dropping mercury electrode and the analytical methods developed on these investigations have been called "polarography". Thus was provided the polarograph in its early years with the automatic instrumentation that is essential to the exploitation of any physicochemical method in practice.

In 1924 he was appointed to Professor of the Imperial University of Kyoto (Kyoto University at present) and held the chair of Professror of Wood Chemistry in the Department of Agricultural Chemistry, where he remained untill 1942 when he was appointed to the Vice-President of the Research Institute of Science of Manchuria (Tairiku-Kagakuin). He also held a chair in the Chemical Research Institute of Kyoto University since its establishment in 1927. In Kyoto University he organized good 
scientific group and carried out many outstanding works not only in polarography but also in the field of wood chemistry and related subjects. As he continued the polarographic study of organic substances, he became especially interested in clarifing the correlation of polarographic reduction potential of organic compounds with their structure. The "polarographic electronegativity rule" (Collection Czech. Chem. Communs., 10368 (1938)) represented the crystallization of the ideas resulting from the extensive studies of organic polarography. He also made many pioneering works successfully in applying polarography in analysis of biological materials, foods and fermentation products. In the field of wood chemistry he extensively studied pulping of woods and grasses of subfrigid and tropical zones. He succeeded in manufacturing superior rayon pulp by sulfite process from Manchurian larch. He first discovered the presence of mannan in certain hardwoods of subfrigid zones. He also studied on the utilization of Saghalien tundra and made pioneering work for manufacturing fibre board from tundra, which led him to fundamental studies on the electric disturbance of adsorbed water molecules on fibre by alternating electric field of high frequency and on physics and chemistry of surfrce phenomena.

After the II World War he took service in People's Republic of China and returned to his home country in 1953. In 1954 he was appointed to Professor of Nagoya University, from which he retired by age limit in 1959.

He was awarded the Royal Grant for his study of Saghalien tundra. He received the Academic Prize of the Agricultural Society of Japan in 1952 and the Royal Prize of the Japanese Academy of Sciences in 1954 for his outstanding contribution to polarography.

In Nagoya he felt ill and, after retirement, rested quietly under medical care at his home in Kyoto. Fortunately he was getting well, so well that he looked almost normal in health. On his last day on earth, according to Mrs. Shikata, in the morning he was visited from his grandson's teacher of elementary school. It was a very fine day of May. In the afternoon he enjoyed some talks with his family. He looked feeling so fine and peaceful and talked to her that it might be such a fine day when I should be sent to heaven; in the evening he passed away in peace. Let me allow here to quote Mrs. Shikata's short poem (waka) dedicated to him at his death, though my knowledge of English is too poor to translate it into English.

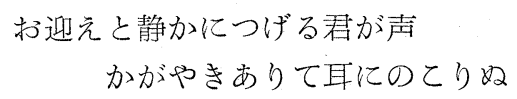

\section{千代子 \\ (Chiyoko Shikata)}

Professor Shikata was a man of hard work and of deep thinking. He was profoundly interested in everything that happened around him and was always seeking explanations. He was intolerant of lose thinking. He was an enthusiastic and inspiring leader always readay with encouragement, advice and help. Above all he was warm-hearted. He will be sadly missed by his many friends and pupils. 


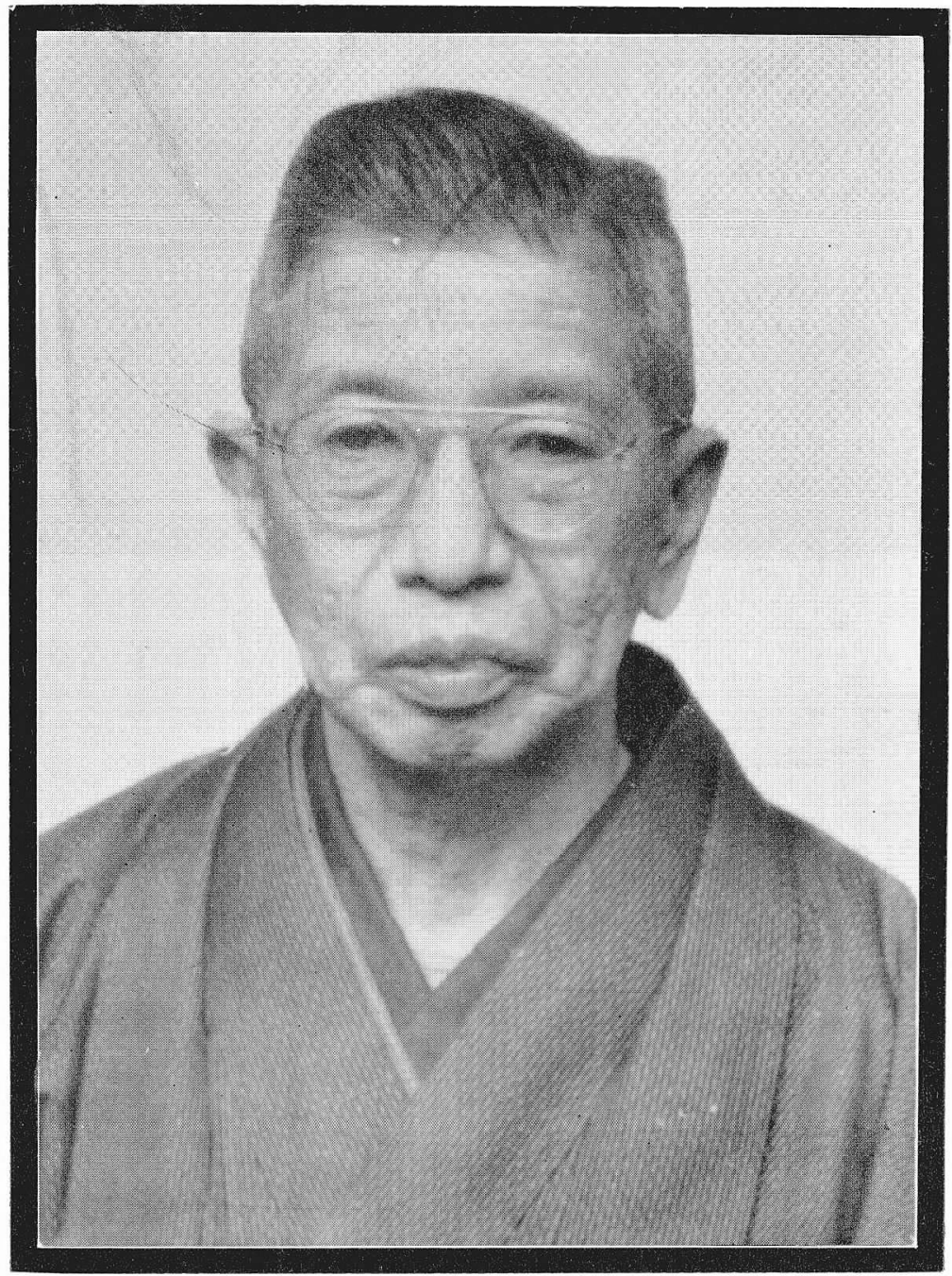

The Honorary President

Professor Dr. Masuzo Shikata

$$
1895-1964
$$

